Translation Issues in Language and Law 
This page intentionally left blank 


\section{Translation Issues in Language and Law}

Edited by

Frances Olsen

University of California

Alexander Lorz

Düsseldorf University

and

Dieter Stein

Düsseldorf University

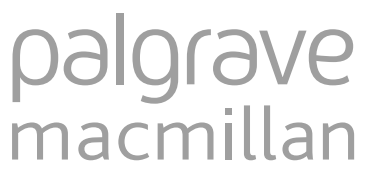




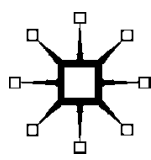

Selection and editorial matter (c) Frances Olsen, Alexander Lorz and Dieter Stein 2009

Chapters (C) their individual authors 2009

Softcover reprint of the hardcover 1st edition 2009 978-0-230-20350-1

All rights reserved. No reproduction, copy or transmission of this publication may be made without written permission.

No portion of this publication may be reproduced, copied or transmitted save with written permission or in accordance with the provisions of the Copyright, Designs and Patents Act 1988, or under the terms of any licence permitting limited copying issued by the Copyright Licensing Agency, Saffron House, 6-10 Kirby Street, London EC1N 8TS.

Any person who does any unauthorized act in relation to this publication may be liable to criminal prosecution and civil claims for damages.

The authors have asserted their rights to be identified as the authors of this work in accordance with the Copyright, Designs and Patents Act 1988.

First published 2009 by

PALGRAVE MACMILLAN

Palgrave Macmillan in the UK is an imprint of Macmillan Publishers Limited, registered in England, company number 785998, of Houndmills, Basingstoke, Hampshire RG21 6XS.

Palgrave Macmillan in the US is a division of St Martin's Press LLC, 175 Fifth Avenue, New York, NY 10010.

Palgrave Macmillan is the global academic imprint of the above companies and has companies and representatives throughout the world.

Palgrave ${ }^{\circledR}$ and Macmillan ${ }^{\circledR}$ are registered trademarks in the United States, the United Kingdom, Europe and other countries.

ISBN 978-1-349-30134-8 ISBN 978-0-230-23374-4 (eBook)

DOI $10.1057 / 9780230233744$

This book is printed on paper suitable for recycling and made from fully managed and sustained forest sources. Logging, pulping and manufacturing processes are expected to conform to the environmental regulations of the country of origin.

A catalogue record for this book is available from the British Library.

Library of Congress Cataloging-in-Publication Data

Translation issues in language and law / edited by Frances

Olsen, Alexander Lorz, and Dieter Stein.

p. $\mathrm{cm}$.

"This volume represents a selection of papers from the International Conference on Language and Law at Heinrich-Heine-University Dusseldorf, Germany, in May 2006, jointly organized by the University of California at Los Angeles Law School, Heinrich-Heine-University University Law School and the Department of English Language and Linguistics"-Preface [?]

Includes bibliographical references and index.

ISBN 978-1-349-30134-8 (alk. paper)

1. Law - Language - Congresses. 2. Law - Translating - Congresses.

I. Olsen, Frances E. II. Lorz, Alexander. III. Stein, Dieter, 1946-

K213,T7342009

340'.14-dc22

2008030453

$\begin{array}{llllllllll}10 & 9 & 8 & 7 & 6 & 5 & 4 & 3 & 2 & 1\end{array}$

$\begin{array}{llllllllll}18 & 17 & 16 & 15 & 14 & 13 & 12 & 11 & 10 & 09\end{array}$ 


\section{Contents}

List of Figures vii

List of Tables viii

Acknowledgement ix

Notes on the Contributors $\quad \mathrm{x}$

Introduction: Forensic Translation - Practical Issues

and their Theoretical Underpinnings

Dieter Stein

\section{Part I Language and Different Law Cultures}

1 Legal Cultures - Legal Languages

Uwe Kischel

2 Language as a Barrier to Comparative Law

Oliver Brand

3 Statutory Interpretation in the EU: the Augustinian Approach

Lawrence M. Solan

4 Globalizing Trends in Legal Discourse

Maurizio Gotti

5 The Status and Position of Legal Translation:

a Chapter in the Discursive Construction of Societies José Lambert

\section{Part II Handling Legal Discourse in the Modern World}

6 Translation at the Court of Justice of the European Communities

Karen McAuliffe

7 Drafting or Translation - Production of Multilingual Legal Texts

Agnieszka Doczekalska 
8 Legal Translation in Canada: the Genius of Legal Language(s)

Louis Beaudoin

\section{Part III Concrete Problems in Legal Translation}

9 Pitfalls of English as a Contract Language Volker Triebel

10 Isomorphism and Anisomorphism in the Translation of Legal Texts

Enrique Alcaraz Varó

11 Translation as a Dynamic Model in the Development of the Burundi Constitution(s) Jean-Baptist Bigirimana

References

Index 


\section{List of Figures}

7.1 Schema of translation

7.2 Schema of legal translation from one legal system into another

7.3 Schema of legal translation within one legal system

121

11.1 Possible models (matrix) of Burundi constitutional texts 


\section{List of Tables}

3.1 The legal orders and their effects on the three goals 37

3.2 The legal orders and their effects on the three goals 52

4.1 Average sentence length in the corpus analysed 73

$\begin{array}{lll}4.2 & \text { Distribution of sentence types } & 73\end{array}$

4.3 Type and number of occurrences of archaic words 73

$\begin{array}{ll}7.1 \text { Comparison of co-drafting techniques } & 124\end{array}$

7.2 Possibility of the distinction between source and target text in co-drafting methods 127

11.1 Burundi constitutional evolution 205

11.2 Content of the subdivisions of the
constitutional text

11.3 Crucial chapters in the history of Burundi
as illustrated by translations 


\section{Acknowledgement}

This volume would not exist had it not been for the indefatigable and painstaking work by Alexander Tokar, Research Assistant and PhD candidate working with Dieter Stein at the chair for English Language and Linguistics at Heinrich-Heine-University, Düsseldorf. Alexander Tokar has overseen the origination of the volume from the first call for papers for a reviewed volume to seeing the paperwork through in the final stages of administering the volume and overseeing the indexing and proofreading. 


\section{Notes on the Contributors}

Enrique Alcaraz Varó ${ }^{\dagger}$ was Professor of English Language at the University of Alicante.

Louis Beaudoin is Lecturer of Legislative Drafting at the University of Laval (Quebec City).

Jean-Baptist Bigirimana is a $\mathrm{PhD}$ researcher at the Catholic University of Leuven.

Oliver Brand is Assistant Professor of Law at the University of Münster.

Agnieszka Doczekalska is a PhD student at the European University Institute, Florence.

Maurizio Gotti is Professor of English Linguistics at the University of Bergamo.

Uwe Kischel is Professor of Law at the University of Greifswald.

José Lambert is Professor of General Literature at the Catholic University of Leuven.

Alexander Lorz is Professor of Law at the University of Düsseldorf.

Karen McAuliffe is Lecturer at the School of Law at the University of Exeter.

Frances Olsen is Professor of Law at the University of California at Los Angeles.

Lawrence M. Solan is Professor of Law at the Brooklyn Law School.

Dieter Stein is Professor of English Language and Linguistics at the University of Düsseldorf.

Volker Triebel is a Partner at Lovells in Düsseldorf. 